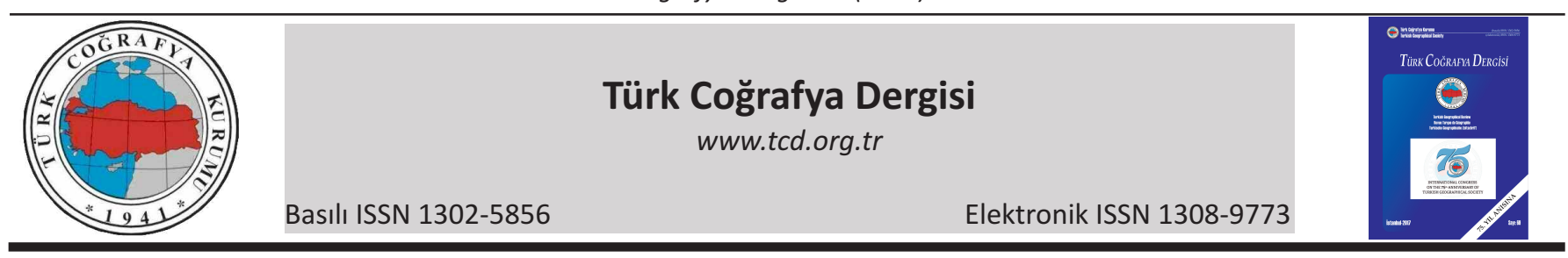

\title{
Türkiye'de ekstrem sıcaklık indislerinin eğilimlerinde şehirleşmenin etkisi
}

\section{Urbanization effect on trends of extreme temperature indices in Turkey}

\author{
Dilek Aykır*a (D) \\ ${ }^{a}$ Ankara Üniversitesi, Sosyal Bilimler Enstitüsü, Fiziki Coğrafya Anabilim Dalı, Ankara.
}

\section{BILGI / INFO}

Geliş/Received: 07.04.2017

Kabul/Accepted: 13.08.2017

Anahtar Kelimeler:

Ekstrem sıcaklık

İklim indisleri

İklim değişimi

Şehir klimatolojisi

Türkiye

Keywords:

Extreme temperature

Climate indices

Climate change

Urban climatology

Turkey

*Sorumlu yazar/Corresponding author

(D. Aykır) dlkaykr@gmail.com

http://doi.org/10.17211/tcd.306742

\begin{abstract}
ÖZ / ABSTRACT
Türkiye, subtropikal kuşaktaki Akdeniz havzasında bulunması sebebiyle iklim değişikliklerinden önemli ölçüde etkilenecek sahalar içinde kalmaktadır. İklim değişikliği dünyanın pek çok bölgesinde ortalama sıcaklıklarda meydana gelen artışlar olarak kendini göstermektedir. Bu çalışmada, Türkiye'deki 1970-2012 yılları arasında 42 meteoroloji istasyonu için şehir ve kır istasyon çiftleri oluşturulmuştur. Bu istasyon çiftlerinin iklim indisleri arasındaki farkların değişimi, 1970-2012 yılları arasını kapsayan rasatları dikkate alınarak incelenmiştir. Bu inceleme için RClimDex programı ve Mann Kendall trend analizi tekniği kullanılmıştr. RClimDex programı 27 adet iklim indisi üretmektir. İndislerden türetilmiş bilgi yalnızca ortalama değerin zaman içinde nasıl değiştiğini değil; aynı zamanda verinin istatistiksel dağılımının nasıl değiştiği konusunda da bilgi içerir. Ayrıca sonuçlar ekstremlerin trendleri hakkında çok önemli bilgiler sağlamaktadır. Bu çalışmada sıcaklık ile ilgili olan 10 indis seçilerek incelenmiştir. Seçilen istasyonların iklim indis farklarında anlamlı artı̧̧ ve azalışlar olduğu, bu artş̧ ve azalışların şehir istasyonlarında kır istasyonlarına göre daha fazla olduğu görülmüştür. Mann Kendall trend analizine göre incelenen tüm istasyon çiftlerinde tropikal gün, yaz günleri, sıcak geceler, sıcak günler, minimum sıcaklıkların minimumları, minimum sıcaklıkların maksimumları indis farkları artma eğilimi görülürken, soğuk devre süresi indis farkında azalma eğilimi gözlenmiştir. Trendlerin çoğu \%5 seviyesinde istatistiksel olarak anlamlıdır.
\end{abstract}

Turkey is located in the Mediterranean Basin, which is most affected by climate change. Climate change is manifested in many parts of the world as an increase in average temperature occurred. In the study, city and rural station pairs were created for 42 meteorological stations in Turkey between 1970 and 2012 periods. The changes in the climatic indices of these station pairs have been examined. RClimDex program and Mann Kendall trend analysis technique were used for this investigation. RClimDex program generates 27 core climate indices. Information derived from indices not only includes how average values change over time but also shows how the statistical distribution of data changes over time. Results also provide crucial information about the trends of the extremes. This study focused on 10 temperature indices. It was observed that selected stations pair's climate indices differences significantly increased or decreased and this increment or decrement was more pronounced in urban stations compared to rural stations. Based on Mann Kendall trend analysis, while differences in station pair's climate indices such as tropical, days, summer days, warm nights, warm days, minimum of minimum temperatures and maximum of minimum temperatures indices differences had increasing trend, only differences of cold spell duration indicator trend showed a decreasing trend. Most of the trends were found to be statistically significant at a level of $5 \%$.

\section{Giriş}

21. yüzyılda tüm dünyada ekstrem olayların şiddet ve frekans eğiliminde artş̧lar gözlenmiştir (IPCC, 2001). Tüm dünyada özellikle 21. yüzyıldan sonra iklimde ısınmanın arttı̆ı görülmektedir. IPCC (IPCC, 2007)' nin önceki değerlendirme raporlarında antropojenik etkinin bu ısınmadaki payını net bir şekilde kabul etmese de son değerlendirme raporunda iklimdeki ısınma ve ekstrem olaylardaki artış trendinde bu faktörün doğrudan etkili olduğunu net bir şekilde ortaya koymuştur (IPCC, 2013). Birçok ülkede uzun dönemli günlük meteorolojik gözlemlerin bulunamaması veya eksikliği, ülkeler ile bölgelere ait çalışmalarda eksikliklere yol açmaktadır. Bundan dolayı ve ayrıca küresel ısınmanın geleceğimize olan etkisinin kavranamaması nedeniyle küresel ölçekte iklim değişikliğinin belirlenmesini güçleştirmektedir. Son yıllarda tüm dünyada gözlemlerin sayısındaki ve buna bağlı olarak iklim ve iklim değişikliği çalışmalarındaki artş̧, daha objektif sonuçların elde edilmesini hızlandırmıştır. 
Alexander vd.'nin 16 sıcaklık indisini ele aldıkları çalışmada, 1951-2003 dönemi için küresel ölçekte dağılım gösteren 200 istasyonun günlük sıcaklıklarını analiz etmişlerdir. Yaz günlerinin yıllık sayılarında, Hindistan'ın büyük bir kısmı ile ABD'nin doğusundaki dar bir alanda azalma, Kanada'nın kuzeyi, Avrupa'nın batısı, Orta Doğu, Avustralya ve Brezilya'nın güneyinde ise anlamlı ölçüde artı̧̧ eğilimi gösterdiği ortaya konulmuştur (Alexander vd., 2006).

Avrupa için yapılan çalışmalara bakıldığında, son 30 yıl içinde yaz günü ve sıcak hava dalgalarının sayılarının arttğı görülmektedir (IPCC, 2013). 1946-1999 yılları arasında Avrupa'daki bazı istasyonların sıcaklık ekstremlerinin incelendiği bir başka çalışmada da, kıtada yaz günleri sayısındaki artşlar işaret edilmektedir. Isınma eğilimi yaz günleri için 42 istasyonun 16'sında istatistiksel olarak anlamlı bulunmuştur (Klein ve Können, 2003). Yaz mevsiminde Akdeniz Havzası'nda deniz suyu sıcaklıkları ve atmosfer dolaşımı ile bağlantılı olarak hava sıcaklıklarının 1950-1999 dönemi için incelendiği bir çalışmada, en serin yazların 1960 'ler ile 1970 'lerin ortaları olduğu ve bu dönemde en serin yazın ise 1976 yılında yaşandığı, 1950'ler, 1980'ler ve 1990 'ların ise daha sıcak yaz mevsimleri ile karakterize olduğu, en yüksek değerlerin 1994 ile 1999 yıllarına rastladığı vurgulanmıştır (Xoplaki vd., 2003).

Türkiye'de minimum ve maksimum sıcaklıklar ile günlük sıcaklık farklarının değişim ve eğilimleri üzerine yapılan çalışmada, Türkiye'nin büyük bir bölümünde 1992 yılına kadar maksimum sıcaklık dizilerinde (ilkbahar dışında) genel bir azalma eğiliminin egemen olduğu ancak bu tarihten sonra, ortalama ve minimum sıcaklık dizilerinde olduğu gibi maksimum sıcaklıklarda da özellikle ilkbahar ve yaz mevsimlerinde artşlar gözlendiği ortaya konulmuştur (Türkeş vd., 2002).

Şensoy vd.'leri, R-Climdex kullanarak 1971-2004 dönemi için 100 istasyon ve 1960-2010 dönemi için 109 istasyon ile yaptkları çalışmada tüm Türkiye'de buz günleri ve donlu günler sayıları azalırken; yaz günleri ve tropik geceler sayıları artmaktadır sonucuna varmışlardır (Şensoy vd., 2008; 2013).

Demircan vd. 2013 yılında 1961-2010 dönemi için 97 istasyon ile yapmış oldukları çalışmada Türkiye ortalama sıcaklıklarında, 1976 yılına kadar bir soğuma, 1961-1990 sıcaklık normalinde de anlamlı olmasa da bir azalış eğilimi gözlenmektedir. 19612010 serisi ve 1981-2010 normalinde kış mevsimi hariç tüm mevsim ile yıllık serilerinde ve 1971-2000 normalinde ise yaz ile yıllık serilerinde anlamlı artış eğilimi gözükmekte olduğunu belirtmişlerdir.

Şensoy vd. "Ankara'da ekstrem sıcaklık indisnin eğilimlerinde şehirleşmenin etkisi" isimli çalışmalarında 1960-2010 döneminde Ankara (şehir) ve Esenboğa (kırsal) için sıcaklık indislerini çalışmışlardır. Donlu günlerde şehirde azalış kırsalda artış eğilimi, serin gecelerde şehre göre kırsalda 4 kat fazla azalma eğilimi ve soğuk devre süresi indikatöründe ise 6 kez fazla azalma eğilimi tespit etmişlerdir. Tropik gecelerde şehre göre kırsalda 7 kat daha fazla ve büyüme sezon uzunluğunda ise 4 kat fazla artış olduğunu bunun da minimum sıcaklıklardaki artş̧ eğilimini gösterdiğini belirtmişlerdir. Bunun ise günlük sıcaklık genişliği indisinde Ankara'da artış Esenboğa'da ise azalış eğilimine neden olduğunu belirtmişlerdir. Ancak yaz günleri, sıcak günler ve sıcak devre süresi indikatörünün maksimum sıcaklık ile ilişkili olduğunu ve güneş yükselimi ile ilgisi nedeniyle şehirleşme etkisi için belirleyici olmadığını ifade etmişlerdir (Şensoy vd.
2015).

Dünyadaki iklim değişikliğine bağlı olarak yaşanan genel ısınma eğilimi en belirgin şekilde şehirlerde hissedilmektedir. Şehirlerde binalar, yollar ve sanayi tesisleri kırsal alanlara göre daha yoğundur. Şehirlerdeki yüzeylerde kullanılan materyaller, binaların geometrik özellikleri ve yükseltileri, kentsel ısı kaynakları, ayrıca hava kalitesi özellikleri değişmiş iklimlerin ana sebepleridir (Marsh, 1991; Landsberg, 1981). Şehirsel yerleşmelerde tercih edilen asfalt, beton, cam ve taş gibi absorbsiyon özelliği yüksek malzemeler, mat, pürüzlü ve koyu renkli yüzeye sahip oldukları için ısıyı emerek depolarlar. Bu durum şehirlerdeki yüzey malzemelerinin enerjiyi tutma ve depolama süresini arttırmaktadır. Şehirlerde güneşışınlarının yansıma değerlerinin düşük oluşu net radyasyonun yükselmesine neden olmakta ve böylece sıcaklık değerlerinde artış yaşanmaktadır. Şehirlerdeki yapılar kırsal ortamlara göre daha çok ısıyı emerler. Açık arazilerde güneş radyasyonu yansımayla dağılırken, şehirlerdeki yüksek binalar aracılığıyla bu yansıyan güneş ışınları tutulur (Gönençgil, 2011). Absorbsiyon ile koyu renkli bina malzemeleri arasında doğru orant bulunmaktadır. Binaların yüksekliğinin artması, hava akımlarının etkisinin zayıflamasına neden olmaktadır. Bu durumda konvektif ve advektif karışmayla gerçekleşen Isı kaybı engellenmektedir (Kum, 2013).

Şehirlerde rüzgârların hızı, kırsal mekânlara göre daha azdır. Güneş ışınları labirent şeklinde kıvrılmaktadır. Böylece radyasyon kanyonları ışınları yansıtarak sıcaklıkların yükselmesine neden olmaktadır. Örneğin, yüksek ve geniş binalar, hâkim rüzgârların sürtünme etkisini arttırarak hâkim rüzgârların hızının düşmesine neden olmaktadır (Hough, 1986). Özellikle şehirlerdeki sanayi tesislerinden, binaların ısıtma ve soğutma sistemlerinden, taşıtlardan kaynaklanan ısı enerjisinin fazla oluşu, şehir iklimini büyük ölçüde etkilemektedir. Fosil yakıtların enerji kaynağı olarak tercih edilmesi bu sorunun ana sebebini teşkil etmektedir. Fabrikalar, egzoz gazları, konutların ısıtılmasından kaynaklanan dumanlar, toz ve is gibi kirleticiler sayesinde havanın bileşimine müdahalede bulunulduğu için, şehirlerde ısı artişı yaşanmaktadır. Şehirlerdeki yüzey materyallerinin geçirimsiz olması nedeniyle yağış hızla yüzey akışına geçerek şehir içlerinde kanalizasyon sistemleri aracılığıyla hızlı bir şekilde toplanmaktadır. Aksine kırsal ortamlarda buharlaşma, enerjinin gizli ısıya çevrilmesinde önemli katkıda bulunur. Bu olay gizli ısı soğutma sürecinde dikkate değer bir etkiye sahiptir. Şehirsel mekânlarda enerji, gizli ısıya dönüşmeden kalır ve ısıtma sürecine katılır (Gallo, 1993). Şehirlerde, gündüz absorbe edilen enerji, gece süresince uzun dalgalı termal ışınım olarak havaya yansır. Bu termal ışıma, gece sıcaklıklarının yükselmesine yol açar. Bu olaya "şehir ısı adası etkisi" denir (Türkeş, 2002).

Acar'ın "Türkiye'de Yaz Mevsimindeki Sıcak Günler ve Sıcak Günlerin Eğilimleri" adlı çalışmasında 91 meteoroloji istasyonun 1970-2006 yılları arasındaki günlük maksimum sıcaklık verileri incelenmiştir. Yaz günlerindeki değişkenlik, Türkiye'nin tüm güney kıyıları boyunca yüksektir. Tropikal günlerdeki değişkenlik Türkiye'nin kuzey kıyılarına doğru artmıştır. MannKendall sınamasına göre, Türkiye'de yaz günü sayıları genel olarak azalma eğilimi içerir. Azalma eğilimleri, istasyonların büyük bir kısmında istatistiksel olarak anlamlıdır. Buna karşılık tropikal gün sayıları, genel olarak artış eğilimi gösterir (Acar, 2013).

Riyad şehrinde şehirleşmeye bağlı sıcaklık değişimleri, kent ve kır istasyonu karşılaştırılarak analiz edilmiştir. Şehir ve kır istas- 
yonlarında yıllık ortalama maksimum ve minimum sıcaklıklarda, minimum sıcaklık, sıcak gece ve sıcak günlerin maksimumunda anlamlı artış eğilimi saptanmıştır. Her iki istasyonda serin gece ve serin gün sayısında belirgin azalış eğilimleri olduğu, genel olarak şehir merkezine yakın istasyonun kırsal istasyona göre daha yavaş bir oranda ısındığı ortaya konulmuştur (Alghamdi ve Moore, 2014).

Şehir merkezlerindeki yapılaşmanın yoğunlaşth̆̆ yerlerde, sıcaklıklar tipik olarak artmaktadır. Şehir sıcaklığının alçalma ve yükselme seyri, termal değişimlerin düzensizliğine rağmen belirgindir. Mega şehirler, kendi termal alanlarını oluşturabilme özelliğine sahiptir. Şehirleşmeye bağlı ısı etkisi, şehirler üzerinde dikey doğrultuda $600-800 \mathrm{~m}$. ye kadar etkili olabilmektedir (Ezber vd., 2007). En yüksek sıcaklık artşları, şehirlerde ortalama minimum değerlerde yaşanmaktadır. Isı adaları, gündüzleri zayıf ve süreksizdir. Aksine geceleri gerçekleşen ısı adaları özellikle yüksek basınç koşulları altında oluşmuşlarsa daha güçlü ve düz formdadır. Şehir yüzeylerinin gün boyunca absorbe ettiği enerjinin geceleri yayılması, türbülansın gündüzlere oranla daha zayıf olması ve bulut örtülerindeki yerel değişimin mekânsal farklılaşmalarının daha az olması bu durumun ortaya çıkışına neden olmuştur. Diğer bir ifadeyle, şehirsel ve kırsal alan arasındaki sıcaklık farkında gündüzleri azalma, geceleri ise artma eğilimi olduğu anlaşılmaktadır (Çiçek, 2005).

\section{Veri ve Yöntem}

İklim değişikliği dünyanın pek çok bölgesinde ortalama sıcakIıklarda meydana gelen artı̧̧ar şeklinde kendini göstermektedir. Bu artışın, şehirlerde ve kırsal kesimlerde eşit olup olmadığının araştırılması, şehir ve kırsal alanlar arasında şehirleşmeden kaynaklanan ekstra bir ısınmanın olup olmadığını araştırmak için seçilen şehir ve kır istasyonları indisleri arasındaki farklara bakılarak araştırılmıştır.

Çalışma için Türkiye'yi etkileyen hava kütlelerinin Türkiye'ye geliş yönleri, coğrafî bölgeler ve uzun dönemli veriye sahip olan meteoroloji istasyonlarının bulunması dikkate alınarak 42 (21 şehir, 21 kır/kasaba) yerleşim yeri seçilmiştir (Şekil 1, Tablo 1).
Çalışmada seçilen istasyonların 1970-2012 dönemine ait günlük maksimum, minimum ve yağış verileri, Meteoroloji Genel Müdürlüğü'nden alınmıştır. Çalışma için iklim değişikliği kapsamında artan sıcaklıklar ve yukarıda bahsedilen çalışmalar da göz önünde tutularak, ayrıca minimum sıcaklıkların artışının şehirleşme ile ilişkisi nedeniyle yaz günleri, tropik geceler, sıcak geceler ve sıcak ile soğuk devrelerin eğilimindeki değişimler seçilmiştir. Öte yandan ekstrem sıcaklık değişimlerini görmek için maksimum sıcaklıkların minimum ile maksimumu, minimum sıcaklıkların maksimumu ile minimumu ve aralarındaki ilişkiyi görmek için günlük sıcaklık genişliği indisi seçilmiştir (Tablo 2).

Tablo 1. Araştırmada kullanılan meteoroloji istasyonları ve coğrafi özellikleri. Table 1. Meteorological stations and their geographical properties used in study

\begin{tabular}{|c|c|c|c|c|}
\hline ŞEHIR & KIR & Enlem(Şehir-Kır) & Boylam(Şehir-Kır) & Yükselti(m) \\
\hline Ankara & Esenboğa & $39^{\circ} 57^{\prime}-33^{\circ} 00^{\prime}$ & $32^{\circ} 53^{\prime}-40^{\circ} 07^{\prime}$ & $891-949$ \\
\hline İzmir & Seferihisar & $38^{\circ} 26^{\prime}-38^{\circ} 12^{\prime}$ & $27^{\circ} 10^{\prime}-26^{\circ} 50^{\prime}$ & $29-22$ \\
\hline Denizli & Güney & $37^{\circ} 47^{\prime}-38^{\circ} 09^{\prime}$ & $29^{\circ} 05^{\prime}-29^{\circ} 04^{\prime}$ & $425-806$ \\
\hline Antalya & Finike & $36^{\circ} 53^{\prime}-36^{\circ} 18^{\prime}$ & $30^{\circ} 42^{\prime}-30^{\circ} 09^{\prime}$ & $42-2$ \\
\hline Düzce & Akçakoca & $40^{\circ} 50^{\prime}-41^{\circ} 05^{\prime}$ & $31^{\circ} 10^{\prime}-41^{\circ} 05^{\prime}$ & $146-10$ \\
\hline Trabzon & Akçaabat & $41^{\circ} 00^{\prime}-41^{\circ} 01^{\prime}$ & $39^{\circ} 43^{\prime}-39^{\circ} 34^{\prime}$ & $30-3$ \\
\hline Van & Başkale & $38^{\circ} 28^{\prime}-38^{\circ} 03^{\prime}$ & $43^{\circ} 21^{\prime}-44^{\circ} 01^{\prime}$ & $1671-2400$ \\
\hline Şanlıurfa & Ceylanpınar & $37^{\circ} 08^{\prime}-36^{\circ} 51^{\prime}$ & $38^{\circ} 46^{\prime}-40^{\circ} 03^{\prime}$ & $549-398$ \\
\hline Diyarbakır & Ergani & $37^{\circ} 54^{\prime}-38^{\circ} 17^{\prime}$ & $40^{\circ} 14^{\prime}-39^{\circ} 46^{\prime}$ & $677-1000$ \\
\hline Edirne & Uzunköprü & $41^{\circ} 40^{\prime}-41^{\circ} 16^{\prime}$ & $26^{\circ} 34^{\prime}-26^{\circ} 41^{\prime}$ & $51-52$ \\
\hline Hatay & Dörtyol & $36^{\circ} 12^{\prime}-36^{\circ} 51^{\prime}$ & $36^{\circ} 10^{\prime}-36^{\circ} 13^{\prime}$ & $100-28$ \\
\hline Isparta & Eğirdir & $37^{\circ} 45^{\prime}-37^{\circ} 52^{\prime}$ & $30^{\circ} 33^{\prime}-30^{\circ} 50^{\prime}$ & $997-920$ \\
\hline Sakarya & Geyve & $40^{\circ} 47^{\prime}-40^{\circ} 31^{\prime}$ & $30^{\circ} 25^{\prime}-30^{\circ} 18^{\prime}$ & $30-100$ \\
\hline Hakkari & Yüksekova & $37^{\circ} 34^{\prime}-37^{\circ} 34^{\prime}$ & $43^{\circ} 16^{\prime}-44^{\circ} 17^{\prime}$ & $1728-1900$ \\
\hline Konya & Karapınar & $37^{\circ} 58^{\prime}-37^{\circ} 43^{\prime}$ & $32^{\circ} 33^{\prime}-33^{\circ} 33^{\prime}$ & 1031-1004 \\
\hline Erzurum & Oltu & $39^{\circ} 55^{\prime}-40^{\circ} 33^{\prime}$ & $41^{\circ} 16^{\prime}-41^{\circ} 59^{\prime}$ & $1758-1322$ \\
\hline Bursa & Keleş & $40^{\circ} 14^{\prime}-39^{\circ} 55^{\prime}$ & $29^{\circ} 00^{\prime}-29^{\circ} 04^{\prime}$ & $100-1063$ \\
\hline Mersin & Anamur & $36^{\circ} 48^{\prime}-36^{\circ} 05^{\prime}$ & $34^{\circ} 38^{\prime}-32^{\circ} 50^{\prime}$ & $3-4$ \\
\hline Sinop & İnebolu & $42^{\circ} 01^{\prime}-41^{\circ} 59^{\prime}$ & $35^{\circ} 10^{\prime}-33^{\circ} 47^{\prime}$ & $32-64$ \\
\hline İstanbul & Şile & $40^{\circ} 43^{\prime}-41^{\circ} 11^{\prime}$ & $29^{\circ} 13^{\prime}-29^{\circ} 37^{\prime}$ & $32-83$ \\
\hline Samsun & Bafra & $41^{\circ} 17^{\prime}-41^{\circ} 35^{\prime}$ & $36^{\circ} 18^{\prime}-35^{\circ} 56^{\prime}$ & $4-20$ \\
\hline
\end{tabular}

Sıcaklık artışına bağıı olarak donlu günler, buz günleri ve serin geceler indisinde azalış trendi olacağı öngörüldüğünden, serin

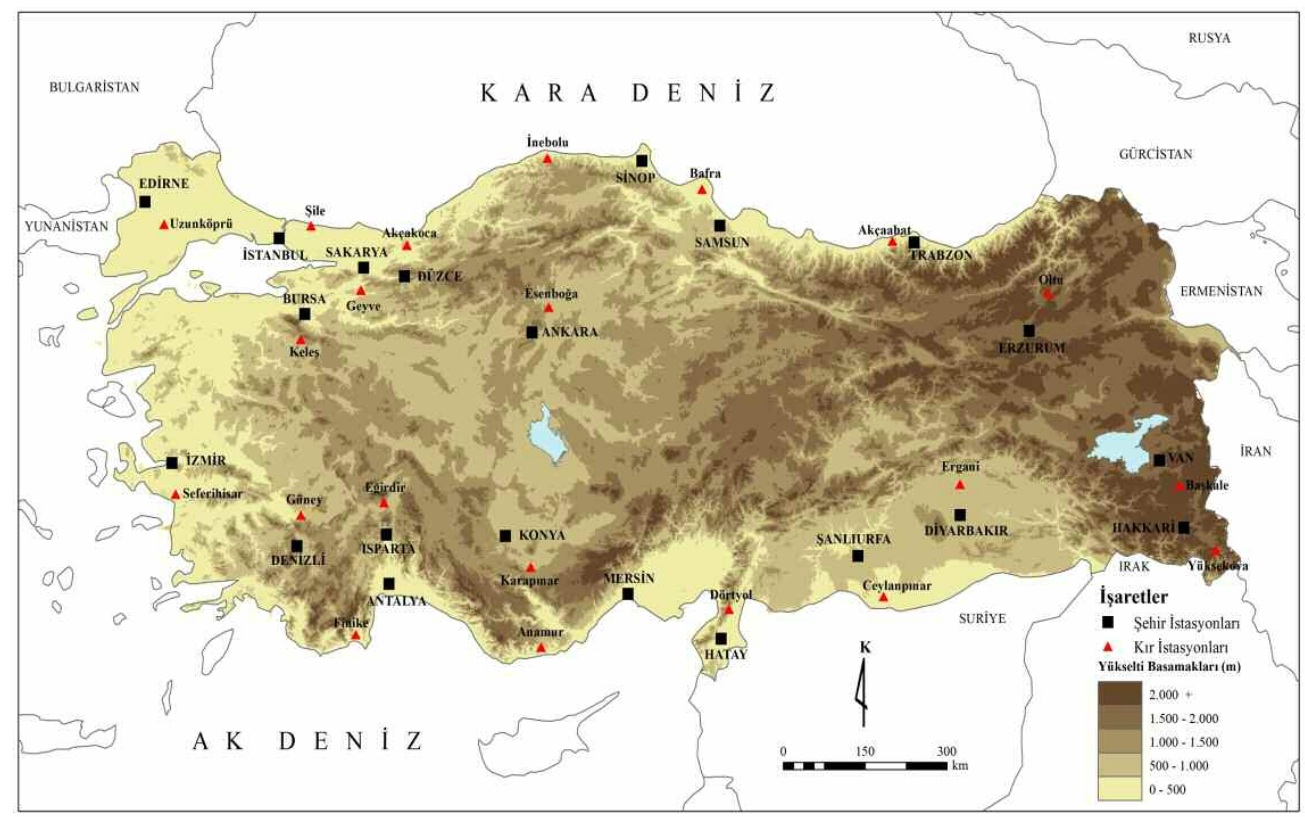

Şekil 1. Lokasyon haritası.

Figure 1. Location map. 
günler ile sıcak günlerin maksimum sıcaklık ile ilintili olması nedeniyle şehirleşme etkisini göstermeyeceği ve büyüme sezon uzunluğunun ise daha çok tarım amaçlı olduğu düşünülerek seçilmemiştir.

Tablo 2. Araştırmada kullanılan iklim indisleri ve tanımlamaları.

Table 2. Climate indices and their descriptions used in study.

\begin{tabular}{|l|l|l|}
\hline Indis & Indis Adı & Tanımlama \\
\hline SU25 & Yaz Günleri & Maksimum Sıcaklık $>25^{\circ} \mathrm{C}$ olduğu günler \\
\hline TR20 & Tropik Geceler & Minimum sıcaklık $>20^{\circ} \mathrm{C}$ olduğu gün \\
\hline TXx & Mak Tmax & Maksimum Sıcaklıkların Maksimumu \\
\hline TNx & Max Tmin & Minimum Sıcaklıkların Maksimumu \\
\hline TXn & Min Tmax & Maksimum Sıcaklıkların Minimumu \\
\hline TNn & Min Tmin & Minimum Sıcakıkların Minimumu \\
\hline TN90p & Sıcak Geceler & Tmin > \%90 persentil olduğu günler \\
\hline WSDI & $\begin{array}{l}\text { SIcak Devre Süresi } \\
\text { Indikatörü }\end{array}$ & $\begin{array}{l}\text { Tmax }>\% 90 \text { persentil olduğu en az } 6 \text { ardışık gün } \\
\text { sayısı }\end{array}$ \\
\hline CSDI & $\begin{array}{l}\text { Soğuk Devre Süresi } \\
\text { Indikatörü }\end{array}$ & $\begin{array}{l}\text { Tmin }<\% 10 \text { persentil olduğu en az } 6 \text { ardışık gün } \\
\text { sayısı }\end{array}$ \\
\hline DTR & Günlük Sıcaklık Genişliği & Tmax-Tmin \\
\hline
\end{tabular}

İndis hesaplamaları için, Dünya Meteoroloji Organizasyonu (WMO) İklim Komisyonu (CCl) ve İklim ve Okyanus - Değişkenlik, Tahmin ve Değişiklik (CLIVAR)'in ortak İklim Değişikliği Algılama, İzleme ve İndisler Uzman Ekibi (ET) 27 temel iklim indisi belirlemiştir. Ekstrem olaylar odaklı bu iklim indislerinin 16 tanesi sıcaklık ile ilgilidir ve Xuebin Zhang ile Feng Yang tarafindan ET adına, ücretsiz R-i̇statistik yazıımı tabanlı, RClimDex isimli bir paket geliştirilmiş olup bu yazılım ile günlük maksimum ile minimum sıcaklık ve yağış miktarları girilerek 27 indis hesaplanmaktadır. Veri setlerinin homojenliğini test etmek için RHtest paketi de mevcuttur. Ayrıca RClimDex ile hesaplama yapmadan veri serisinde kalite kontrolü de yapılabilmektedir. RClimDex ve RHtest paketleri ve kullanıcı rehberleri şu adresten temin edilebilir: http://etccdi.pacificclimate.org/software.shtml.

İndis hesaplamalarında önce veriye homojenlik işlemleri uygulanmıştır. Veri Homojenitesi, homojen iklimsel zaman serisi, değişimi yalnızca iklimsel değişimden kaynaklanan veri şeklinde tanımlanır (Aguilar vd., 2003). Veri homojenitesi için RHtest programı kullanılmıştır. Bu analiz tüm zaman serisine uygulanan doğrusal trend ile iki fazlı regresyon modeline dayanmaktadır (Xiaolan, 2003)

Veriler her bir istasyon için programın formatında düzenlenerek kalite kontrolü yapılmıştır. Verilerin kalite kontrolü, muhtemel kalite sorunlarını yakalamak amacıyla yazılım günlük verinin birçok grafiğini çizmekte ve istatistiksel olarak Xort \pm 4 standart sapma verisinin dışında kalan veriler işaretlenmektedir. Bu verileri kalite kontrol dosyasına yazılmakta kontrol edilerek hatalar düzeltilmekte ya da yerine kayıp değer kondu girilmektedir. Yazılım içindeki kalite kontrol prosedürleri şunlardır:

- Eğer yağış değeri (-) ise kayıp değer olarak kabul edilir (-99.9)

- Tmax < Tmin ise her iki veri de kayıp değer olarak kabul edilir $(-99.9)$

- Eğer veri Xort \pm 4 St. Sapma nın dışında kalıyor ise problemli veri olarak kabul edilir.

Kalite kontrol aşamasından sonra iklim indislerini üretmek için 1970-2012 yılları arası verileri ile RClimDex yazılımı çalıştırılmıştr. RClimDex'in iklim indisleri çıktılarından şehir-kırsal istasyon çiftleri oluşturulmuş ve indis değerleri arasındaki farklar ile zaman serisi oluşturulmuştur. Bu fark zaman serisinin eğilimle- rini analiz etmek için Mann-Kendall Sıra Korelasyon testi uygulanmıştır.

Zamansal bir veri serisinin eğiliminde değişim olup olmadığı, eğer varsa bu değişimin anlamlı bir artı̧ veya azalış gösterip göstermediğini tespit etmek için çeşitli testler kullanılmaktadır. Bunlardan biri olan Parametrik olmayan Mann Kendall Sıra Korelasyon testi, uygulanan zaman serilerinde meydana gelebilecek artma veya azalma yönündeki gidişlerin istatistiksel önemini test etmede oldukça sık kullanılan bir testtir. Bu yöntem de verilerin büyüklüğünden çok sıraları esastır. Eksik verilere müsaade ettiği ve verilerin eldeki belirli bir dağılıma uyma zorunluluğu şart olmadığı için kullanışlıdır (Kalaycı ve Kahya, 1998). Ayrıca testin uygulaması kolay ve sıralar üzerine esas olması ile serisel korelasyon etkisini yok etmiş olmasıdır. Çevresel verilerin zaman serilerinin eğilim analizi, sıcaklık, yağış ve diğer faktörlerin ki değişkenin çalışılan tepkisi etkilenebilir, doğal dalgalanmalarının etkisi altındaki çevre üzerine insan etkisini değerlendirmek için sıklıkla yürütülür (Libiseller ve Grimvall, 2002).

Mann-Kendall test istatistiği;

$$
\mathrm{u}(\mathrm{ti})=\frac{[t-E(t)]}{\sqrt{\operatorname{var}(t)}}
$$

formülü ile hesaplanır. Testin eğilim istatistiği $t$ aşağıdaki gibi hesaplanır.

$$
t=\sum_{n}^{i} n i
$$

Boş hipotez altında t'nin dağılımı, pratik olarak, ortalamalı ve sapmalı normal dağılımı aşağıdaki ifadelerle verilmektedir (Sneyers, 1990).

$$
E(t)=\frac{n(n-1)}{4} \quad \text { ve } \quad \operatorname{var}(t)=\frac{n(n-1) \cdot(2 n+5)}{72}
$$

Bu veri sayıları için $a=0.05$ anlamlılık düzeyinde güven aralığı 1.645 'dir. Bunun anlamı eğer istasyonların Mann-Kendall test istatistiği sonuçları \pm 1.645 aralığında ise "verilerdeki değişimin anlamlı olmadığı" hipotezi kabul edilir. Sonuçlar bu aralık dışında ise verilerdeki değişimin anlamlı olduğu kabul edilir. Güven aralığının 0.05 olması ise çıkan sonucun \%95 doğru olduğunu ifade eder.

\section{Bulgular}

\subsection{Yaz Günleri İndisi}

İklim değişikliğine bağlı olarak artış gösteren sıcaklıklar yaz günleri sayısında da artışa neden olmaktadır. Şehir-kır istasyon çiftlerinin yaz günleri indisi için oluşturulan fark serisi seçilen istasyonların çoğunda anlamlı bir şekilde azalmaktadır. Özellikle Ankara, İstanbul gibi nüfusu fazla olan şehirlerle kır/kasaba istasyonları arasında farklardaki azalma daha belirgindir (Şekil 2). En fazla anlamlı artış eğilimi (3.59 ile) Sakarya ile Geyve arasında görülür. İki yerleşme arasında 1997 yılından sonra farklardaki artı̧̧ eğilimi daha belirgin olmuştur. Yaz günleri indisi fark serisi artı̧̧ eğilimi 28 gün/100 yıl olarak saptanmıştır (Şekil 3). Şehir-kır istasyon çiftleri arasındaki yaz günleri indisi fark serilerindeki en fazla anlamlı azalma eğilimi ise İstanbul ile Şile arasında (-5.98) hesaplanmıştır. Farklardaki azalış eğilimi 1987 yılından sonra belirgin bir hale gelmiştir (Şekil 4). 


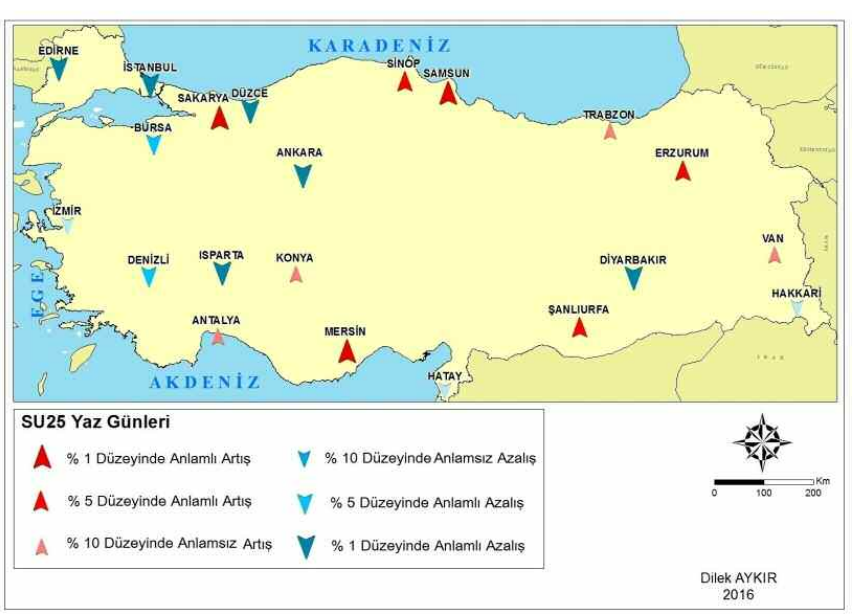

Şekil 2. Yaz günleri indisi fark haritası.

Figure 2. Difference of summer days indices map.

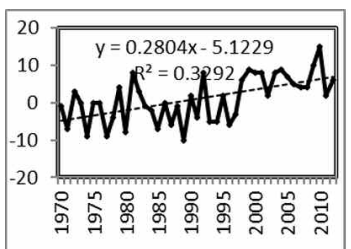

(a)

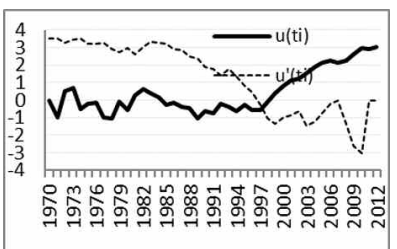

(b)
Şekil 3. a- Doğrusal regresyon analizi, b- Mann Kendall yöntemi ile SakaryaGeyve yaz günleri fark grafiği.

Figure 3. $a$ - Lineer regression analysis, $b$-Difference of summer days in Sakarya - Geyve using by Mann Kendall method.

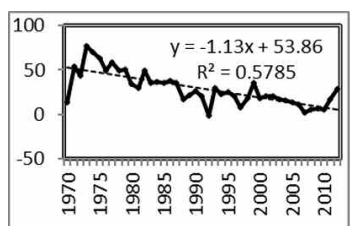

(a)

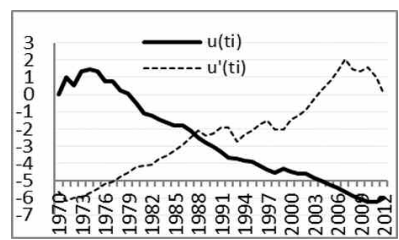

(b)
Şekil 4. a- Doğrusal regresyon analizi, b- Mann Kendall yöntemi ile İstanbulŞile yaz günleri fark grafiği.

Figure 4. $a$ - Lineer regression analysis, $b$-Difference of summer days in Istanbul-Şile using by Mann Kendall method.

\subsection{Tropik Geceler Indisi}

Yaz aylarında şehirleşme nedeniyle minimum sıcaklıkların artşına bağlı olarak $20^{\circ} \mathrm{C}$ üzerindeki minimum sıcaklıklara sahip gün sayıları artı̧ göstermektedir. 21 istasyon çiftinin 13'ünde tropik geceler sayıları indisnin farkında ( 9 'unda anlamlı olmak üzere) artş görülürken 8'inde (4'de anlamlı olmak üzere) azalış görülmektedir. Türkiye'nin batı yarısındaki istasyonlarda genellikle tropik gün sayıları indisnin farkında artı̧ görülürken doğusunda azalış görülmektedir (Şekil 5). Yapılan doğrusal regresyon analizinde en yüksek anlamlı artış eğilimi İstanbul ile Şile arasında (6.12) gözlenirken; en düşük anlamlı azalış eğilimi ise Antalya ile Finike arasında (-5.87) görülmektedir. İstanbul ile Şile arasındaki artış eğilimi 1993 yılından, Antalya ile Finike arasındaki azalış eğilimi 1983 yılından itibaren belirgin hale gelmiştir (Şekil 6-7). İstasyonlardaki tropik geceler farkı tüm Türkiye'de genel olarak anlamlı artış eğilimi göstermektedir. Özellikle karasal ve Karadeniz kesimlerindeki artşlar belirgindir. Şehir-kır istasyon çiftleri arasındaki tropik gecelerde bu anlamlı artış şehirleşme etkisinin sıcaklıklar ve sayılı günler üzerindeki etkisini ortaya koymaktadır. Farkların azalma eğilimi gösterdiği istasyonlarda farklardaki azalmasının nedeni ise istasyon çiftlerinin farklı coğrafî konumları sebebiyle farklı iklim özelliği göstermesine bağlı olduğu düşünülmektedir. Bu tür çalışmalarda istasyon çiftleri seçilirken coğrafî benzerlik ve iklim etki alanlarına dikkat edilmesi gerekmektedir.

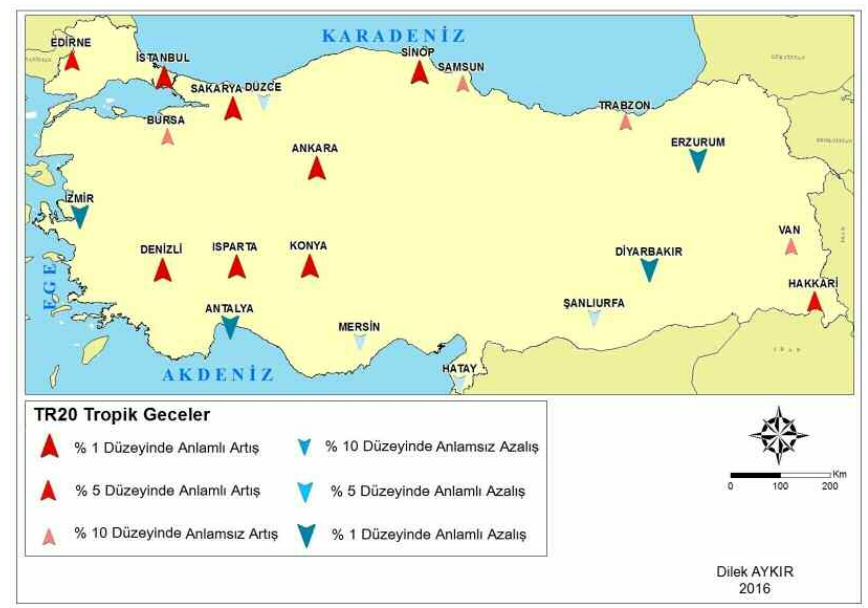

Şekil 5. Tropik geceler indisi fark haritası.

Figure 5. Difference of tropical nights indices map.

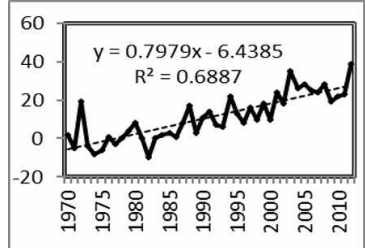

(a)

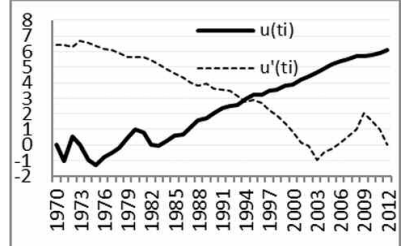

(b)
Şekil 6. a- Doğrusal regresyon analizi, b- Mann Kendall yöntemi ile İstanbulŞile tropik geceler artış fark grafiği.

Figure 6. $a$ - Lineer regression analysis, $b$-Difference of tropical nights in istanbul-Şile using by Mann Kendall method.

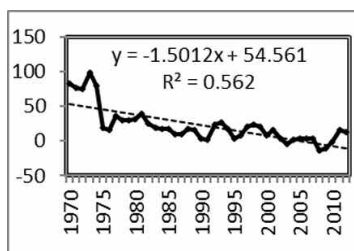

(a)

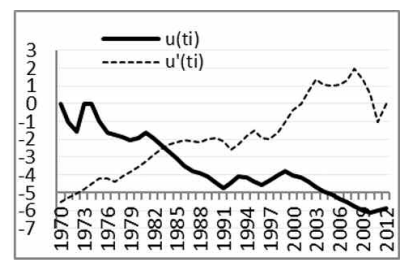

(b)
Şekil 7. a- Doğrusal regresyon analizi, b- Mann Kendall yöntemi ile Antalya-Finike tropik geceler azalış fark grafiği.

Figure 7. $a$-Lineer regression analysis, $b$-Difference of tropical nights in Antalya-Finike using by Mann Kendall method.

\subsection{Maksimum Sıcaklıkların Maksimumu İndisi}

Şehirleşmenin maksimum sıcaklıklar üzerindeki etkisi azdır. Çünkü şehri oluşturan yüzeylerin termal özellikleri ve kanyon etkisi maksimum sıcaklıkları minimum sıcaklardan daha az etkiler. Maksimum sıcaklıkların artmasındaki esas etken güneşlenme süresi ile şiddeti ve ülkemize güneyden gelen sıcak hava dalgalarıdır. Bu nedenle günlük maksimum sıcaklıkların maksimumunda farkların eğilimleri incelenen istasyon çiftlerinin büyük kesiminde anlamsız eğilim göstermektedir (Şekil 8). En yüksek anlamlı eğilim artışı Urfa ile Ceylanpınar (3.65), en düşük anlamlı azalış eğilimi ise, Diyarbakır ile Ergani (-6.10) arasında görülür (Şekil 9-10). 


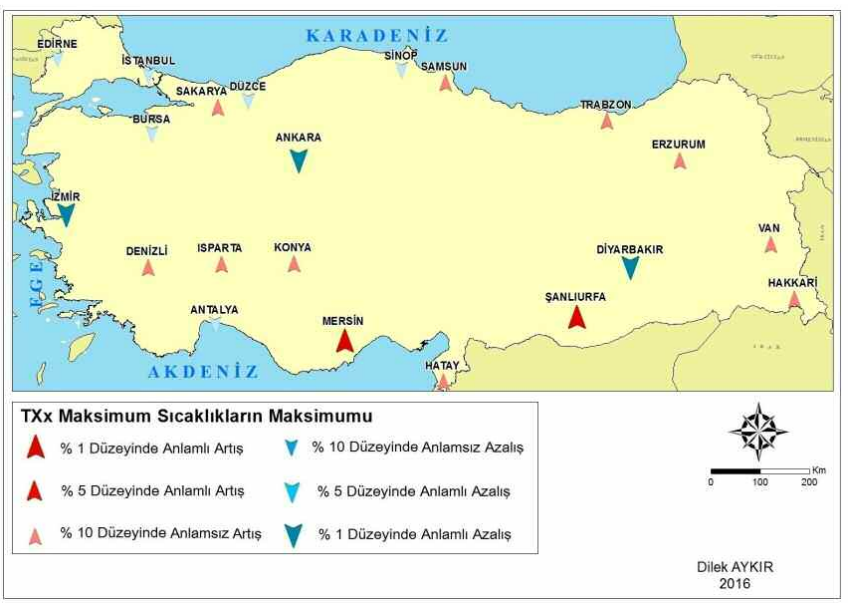

Şekil 8. Maksimum sıcaklıkların maksimumu indisi fark haritası.

Figure 8. Difference of maximum of maximum temperatures indices map.

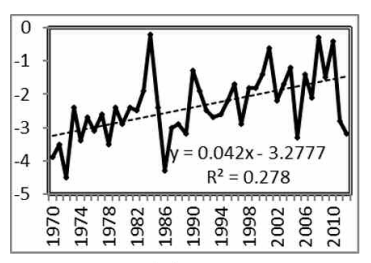

(a)

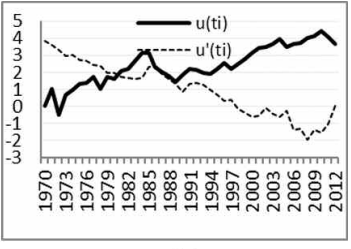

(b)
Şekil 9. a- Doğrusal regresyon analizi, b- Mann Kendall yöntemi ile Urfa-Ceylanpınar maksimum sıcaklıkların maksimumu fark artış grafiği.

Figure 9. $a$-Lineer regression analysis, $b$-Difference of maximum of maximum temperatures in Urfa-Ceylanpınar using by Mann Kendall method.

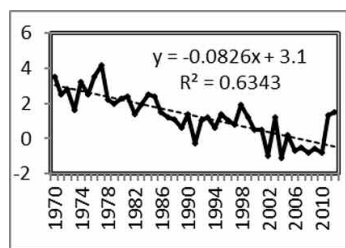

(a)

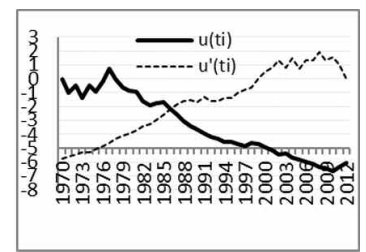

(b)
Şekil 10. a- Doğrusal regresyon analizi, b- Mann Kendall yöntemi ile Diyarbakır-Ergani maksimum sıcaklıkların maksimumu fark azalış grafiği.

Figure 10. $a$-Lineer regression analysis, $b$-Difference of maximum of maximum temperatures in Diyarbakır-Ergani using by Mann Kendall method.

\subsection{Minimum Sıcaklıkların Maksimumu İndisi}

Dünya'da özellikle şehirleşme soncunda minimum sıcaklıklar artı̧ göstermektedir. Bu durum günlük minimum sıcaklıkların maksimumunu artş̧ şeklinde etkilemektedir. Şehirleşmenin belirgin olduğu alanlarda minimum sıcaklıklar daha hızlı artış göstermektedir. Buna bağlı olarak şehir ve kır/kasaba istasyon çiftlerinde de şehirleşmeye bağlı olarak farkların artması beklenmektedir.

Incelenen 21 istasyon çiftinden sadece Erzurum/Oltu çiftinde 0,01 anlamlılık düzeyinde azalma görülürken, Antalya/Finike çiftinde 0,05 düzeyinde azalış dikkati çekmektedir. Diğer istasyonlarda ise artı̧ görülmektedir. Yani şehir özelliği gösteren alanlarda şehirleşme sonucunda günlük minimum sıcaklıkların maksimumunda daha hızlı artış olmaktadır (Şekil 11). En belirgin fark eğilimi, Denizli/Güney istasyon çiftinde hesaplanmıştir. Bu fark $7,5^{\circ} \mathrm{C} / 100$ yıllık bir hız ile artmaktadır. Erzurum/Oltu istasyon çiftinde ise fark, Oltu istasyonunda şehirleşme artışının daha hızlı olması nedeniyle $6,6^{\circ} \mathrm{C} / 100$ yıllık bir hızla azalmaktadır (Şekil 12-13).

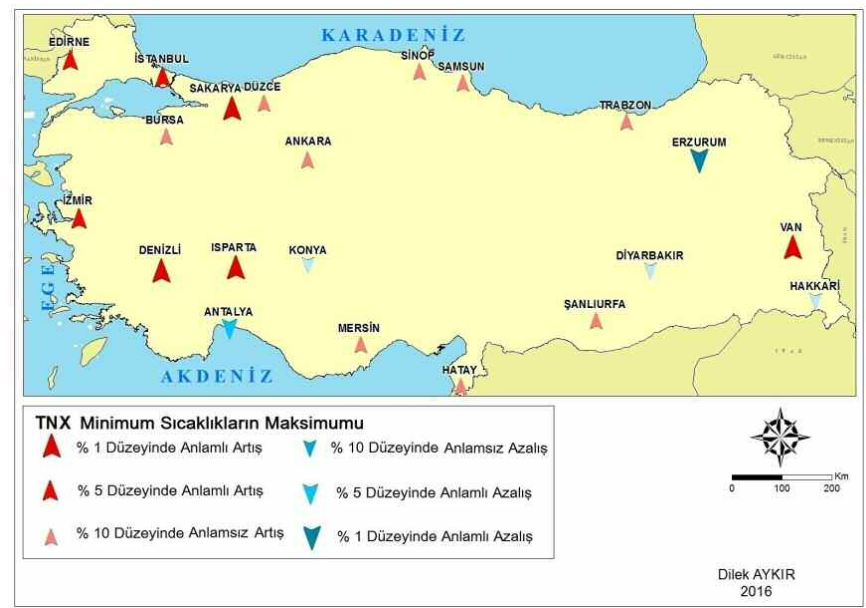

Şekil 11. Minimum sıcaklıkların maksimumu indisi fark haritası. Figure 11. Difference of maximum of maximum temperatures indices map.

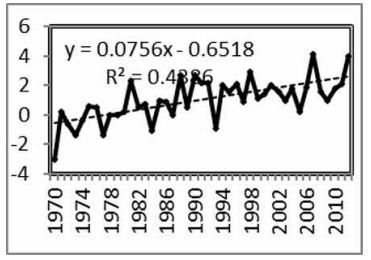

(a)

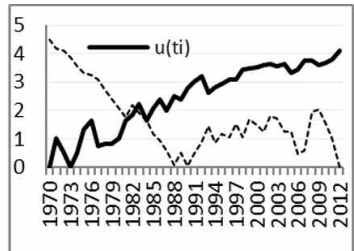

(b)
Şekil 12. a- Doğrusal regresyon analizi, b- Mann Kendall yöntemi ile DenizliGüney minimum sıcaklıkların maksimumu fark artış grafiği.

Figure 12. a-Lineer regression analysis, $b$-Difference of maximum of minimum temperatures in Denizli-Güney using by Mann Kendall method.

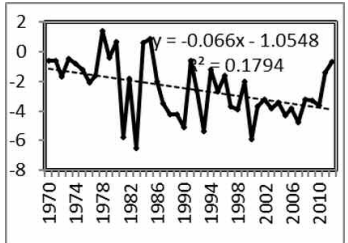

(a)

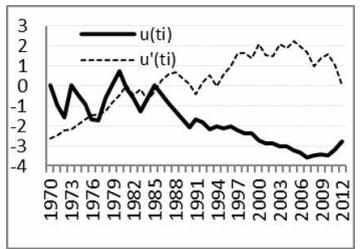

(b)
Şekil 13. a- Doğrusal regresyon analizi, b- Mann Kendall yöntemi ile ErzurumOltu minimum sıcaklıkların maksimumu fark azalış grafiği.

Figure 13. $a$-Lineer regression analysis, $b$-Difference of maximum of minimum temperatures in Erzurum-Oltu using by Mann Kendall method.

\subsection{Maksimum Sıcaklıkların Minimumu İndisi}

Günlük maksimum sıcaklıkların minimumu küresel ısınma bakımından önemli bir göstergedir. Ancak şehirleşmenin iklim üzerindeki etkilerini ortaya koyması açısından belirleyici değildir. Çünkü şehirleşme minimum sıcaklıkları maksimum sıcaklıklardan daha belirgin olarak etkilemektedir. İncelenen istasyonların 18 'inde günlük maksimum sıcaklıkların minimumunun farklarında azalış veya artış eğilimi anlamlı değildir (Şekil 14). En yüksek anlamlı eğilim artş̧ Van ile Başkale'de (3.65), en düşük anlamlı eğilim azalışı ise Hakkâri ile Yüksekova arasında (-4.76) gözlenmektedir. Artış eğilimi 1994, azalış eğilimi 2000 yılından sonra belirgin hale gelmiştir (Şekil 15-16).

\subsection{Minimum Sıcaklıkların Minimumu İndisi}

Günlük minimum sıcaklıkların minimumu, yani ekstrem minimum sıcaklıklar dünya genelinde yükselme eğilimindedir. Şehirleşmenin minimum sıcaklıklar üzerine olan etkisi üzerine yapılan çalışmada "Kentsel boyut şehir ısı adası üzerinde etkilidir". Dolayısıyla hızlı şehirleşme sürecinde minimum sıcaklıklar 
üzerinde en büyük etkiyi yapmaktadır (Mohsin ve Gough, 2012).

En yüksek ortalama anlamlı artış eğilimi Isparta ile Eğirdir arasında (4.91), en düşük anlamlı azalış eğilimi Erzurum ile Oltu arasında (-5.95) saptanmıştır (Şekil 18-19). Minimum sıcaklıkların minimumundaki farklardaki artş eğilimi Türkiye'nin batısında yer alan istasyonlarda, azalış eğilimi ise doğu ve kuzeyde yer alan istasyonlarda görülmektedir (Şekil 17).

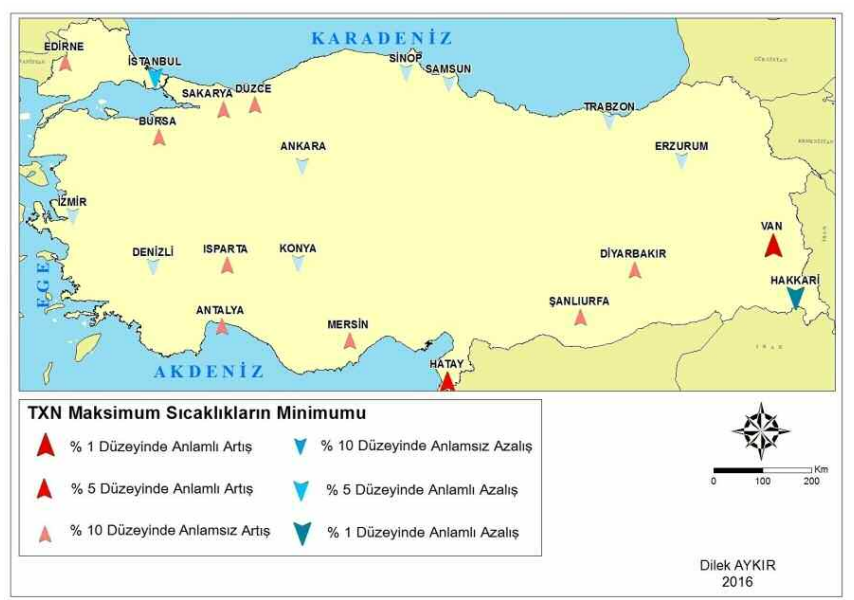

Şekil 14. Maksimum sıcaklıkların minimumu indisi fark haritası.

Figure 14. Difference of minimum of maximum temperatures indices map.

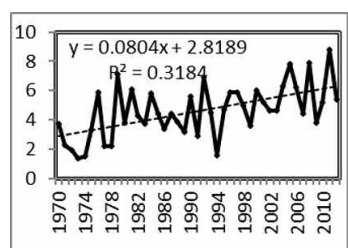

(a)

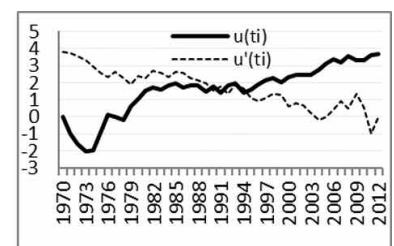

(b)
Şekil 15. a- Doğrusal regresyon analizi, b- Mann Kendall yöntemi ile Van-Başkale maksimum sıcaklıkların minimumu fark artış grafiği.

Figure 15. $a$-Lineer regression analysis, $b$-Difference of minimum of maximum temperatures in Van-Başkale using by Mann Kendall method.

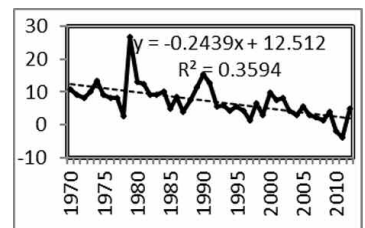

(a)

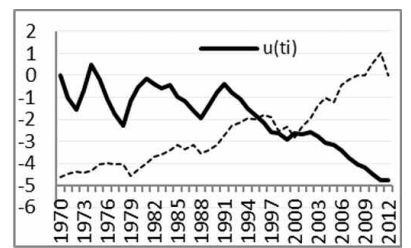

(b)
Şekil 16. a- Doğrusal regresyon analizi, b- Mann Kendall yöntemi ile HakkariYüksekova maksimum sıcaklıkların minimumu fark azalış grafiği.

Figure 16. $a$-Lineer regression analysis, $b$-Difference of minimum of maximum temperatures in Hakkari-Yüksekova using by Mann Kendall method.

\subsection{Sıcak Geceler İndisi}

İklim değişikliğine bağlı küresel ısınma ve şehirleşme sıcak geceler sayılarının artışına sebep olmaktadır. IPCC raporları da tüm dünyada sıcak geceler sayısının arttı̆ını ortaya koymaktadır. Türkiye'nin bat yarısında ve güneyindeki istasyon çiftlerinde sıcak geceler indis farklarında anlamlı artşlar görülmektedir. Bu durum şehir istasyonlarında sıcak geceler sayısının daha hızlı arttğını ortaya koymaktadır. Türkiye'nin doğusundaki iki istasyonda ise sıcak geceler indis farklarında anlamlı azalma görülmektedir. Bu durum, kır/kasaba istasyonlarında sıcak geceler sayılarının daha hızlı arttı̆ını ortaya koymaktadır. Ancak sıcak geceler farklarının azaldığı istasyonların

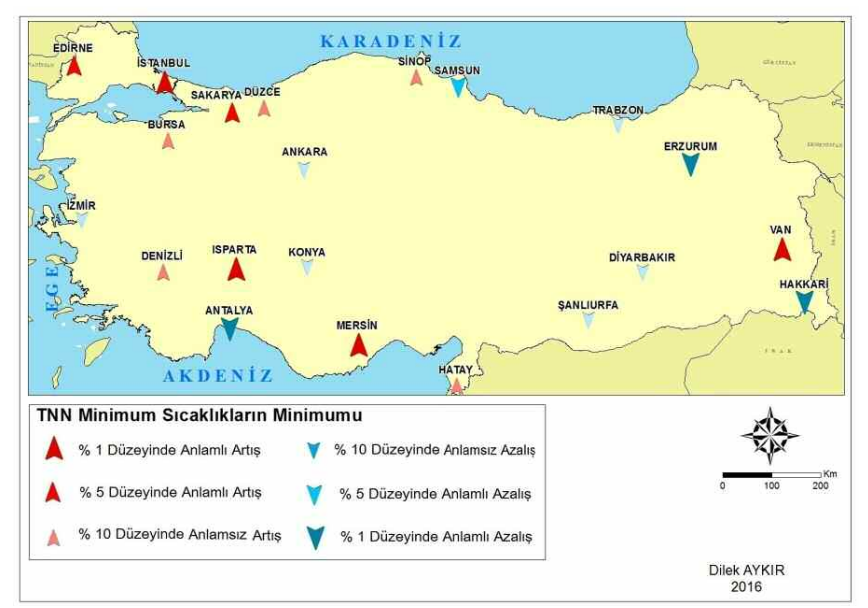

Şekil 17. Minumum sıcaklıkların minimumu indisi fark haritası.

Figure 17. Difference of minimum of minimum temperatures indices map.

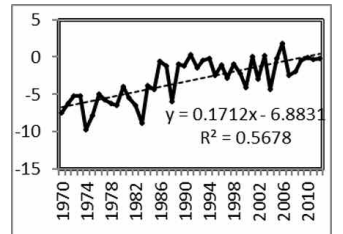

(a)

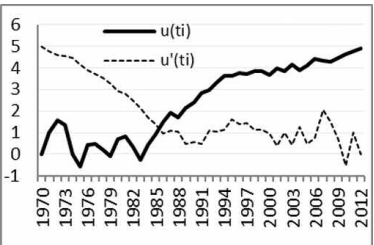

(b)
Şekil 18. a- Doğrusal regresyon analizi, b- Mann Kendall yöntemi ile IspartaEğirdir minimum sıcaklıkların minimumu fark artı̧ grafiği.

Figure 18. $a$-Lineer regression analysis, $b$-Difference of minimum of minimum temperatures in Isparta-Eğirdir using by Mann Kendall method.

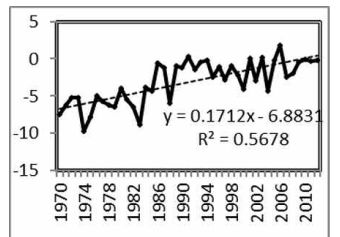

(a)

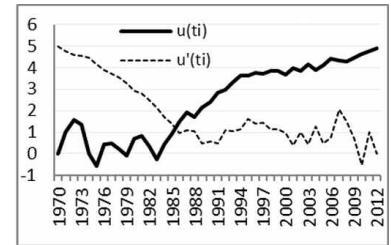

(b)
Şekil 19. a- Doğrusal regresyon analizi, b- Mann Kendall yöntemi ile ErzurumOltu minimum sıcaklıkların minimumu azalış fark grafiği.

Figure 19. $a$-Lineer regression analysis, $b$-Difference of minimum of minimum temperatures in Erzurum-Oltu using by Mann Kendall method.

çoğunda anlamlılık düzeyleri 0,10 iken, artı̧ gösteren istasyonlarda 0,01 düzeyindedir. Bu, tüm Türkiye'de sıcak gece sayılarında şehirleşmeye bağlı olarak artış eğiliminin daha belirgin olduğunu göstermektedir. (Şekil 20). Farklardaki en yüksek anlamlı artş eğilimi Sakarya ile Geyve arasında (6.27) görülürken, en düşük anlamlı azalma eğilimi Erzurum ile Oltu arasında (-4.59) görülür. Farklardaki artı̧̧ ve azalış eğilimi söz konusu yerleşmelerde 1990'lardan sonra daha belirgin olarak görülmektedir.

Sakarya ile Geyve arasındaki artı̧ eğilimi 40 gün/100 yıl, Erzurum ile Oltu arasındaki azalış eğilimi 43 gün/100 yıl şeklindedir (Şekil 21-22). Sıcak geceler, seçilen istasyonların çoğunda artmaktadır. Şehirlerde kırsal kesimlere göre sıcak geceler sayısının daha fazla artmasını, şehir nüfusunun giderek artması, yeşil alanların azalması, asfalt yüzeyler, yüksek betonarme yapıların artması, sanayi merkezlerinin şehir içinde kalması ve ŞıA etkisinin artmasına bağlayabiliriz (Türkoğlu vd., 2012). 


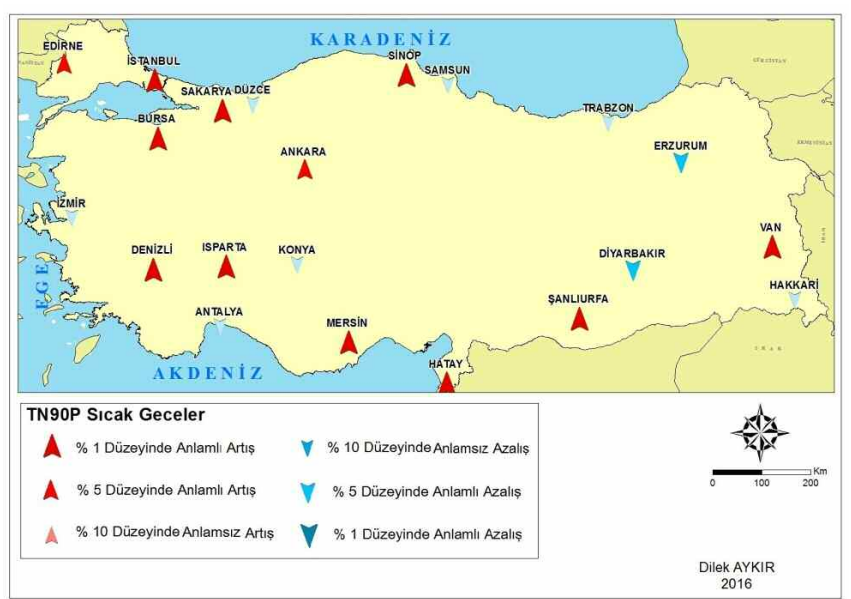

Şekil 20. Sıcak geceler fark indisi haritası.

Figure 20. Difference of minimum of minimum temperatures indices map.

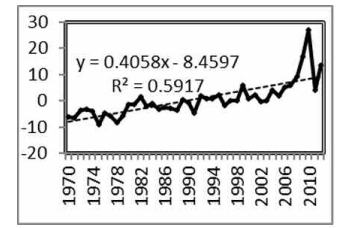

(a)

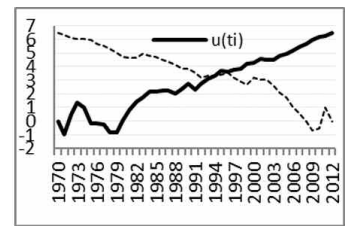

(b)
Şekil 21. a- Doğrusal regresyon analizi, b- Mann Kendall yöntemi ile SakaryaGeyve sıcak geceler fark grafiği.

Figure 21. a-Lineer regression analysis, $b$-Difference of warm nights in Sakarya-Geyve using by Mann Kendall method.

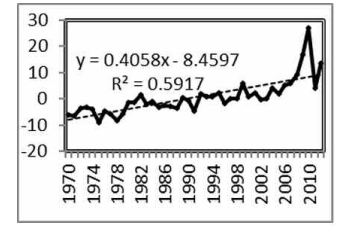

(a)

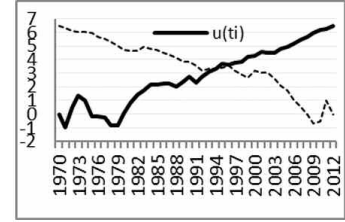

(b)
Şekil 22. a- Doğrusal regresyon analizi, b- Mann Kendall yöntemi ile ErzurumOltu sıcak geceler fark grafiği.

Figure 22. a-Lineer regression analysis, $b$ - Difference of warm nights in Erzurum-Oltu using by Mann Kendall method.

\subsection{Sıcak Devre Süresi İndisi}

Maksimum sıcaklığın (Tmax) \%90 persentilinden büyük olduğu en az 6 ardışık gün sıcak devre olarak tanımlanmaktadır. Bu tarif sıcak hava dalgasını anlatmaktadır. Sıcak hava dalgası küresel iklim sistemlerinin bir sonucudur ve şehirleşmeden bağımsızdır. Buna bağlı olarak incelenen istasyon çiftlerinin pek çoğunda sıcak devre süresi indis farklarında azalış görülmektedir (Şekil 23). Sıcak devre süresi indis farklarında neredeyse tüm istasyonlarda (şehir-kır) anlamlı azalış olması tüm istasyonların genel bir ısınma trendinde olduğunun bir ispatıdır. Şehir istasyonlarında sıcak devre süresindeki artış kır istasyonlarına göre daha fazladır. Bu da genel ısınma trendinin yanında kentlerde bu sürenin daha fazla arttı̆ını göstermektedir.

\subsection{Soğuk Devre Süresi İndisi}

Diyarbakır ile Hakkâri istasyonları dışındaki istasyon çiftlerinde soğuk devre süresinin farkı azalmaktadır. Bu azalma eğilimi Urfa/Ceylanpınar Erzurum/Oltu istasyon çiftlerinde 0,10 düzeyinde, Bursa/Keleş istasyon çiftinde 0,05 düzeyinde anlamlı iken diğer istasyon çiftlerinde 0,01düzeyinde anlamlıdır (Şekil
24). Genel olarak seçilen şehir ve kır istasyonlarının soğuk devre süreleri arasındaki fark anlamlı olarak azalmaktadır. Bu durum şehirlerdeki ısınma etkisi ile minimum sıcaklıkların \%10 persentilinden küçük olduğu 6 ardışık günün artışının şehirlerde daha az görüldüğünü, buna karşın kasaba/kır istasyonlarında bu etkinin devam etmesi aradaki farkın azalmasına neden olmaktadır. Şehir-kasaba/kır çiftlerinde soğuk devre süresinin azalması şehirleşme etkisiyle soğuk hava dalgalarının şehirlerde daha az etkili olduğunu ortaya koymaktadır.

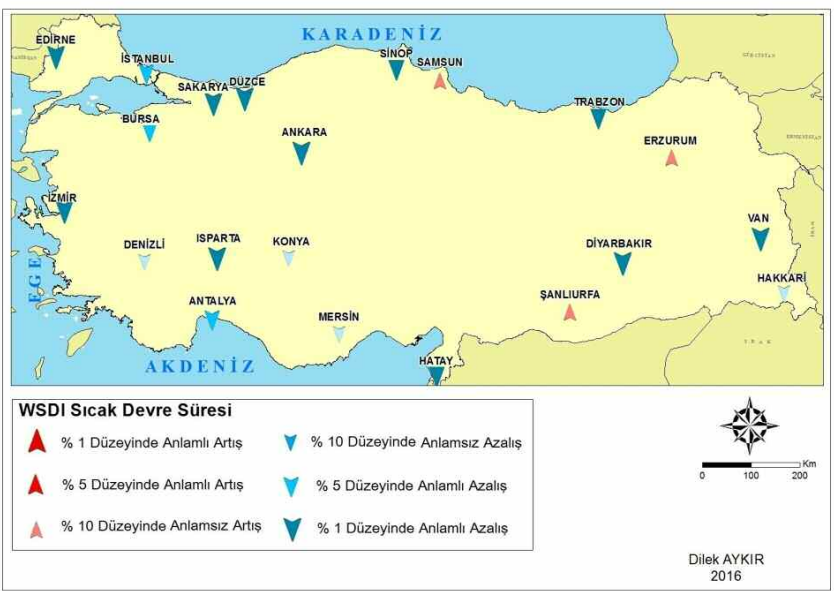

Şekil 23. Sıcak devre süresi indisi fark haritası.

Figure 23. Difference of warm period indices map.

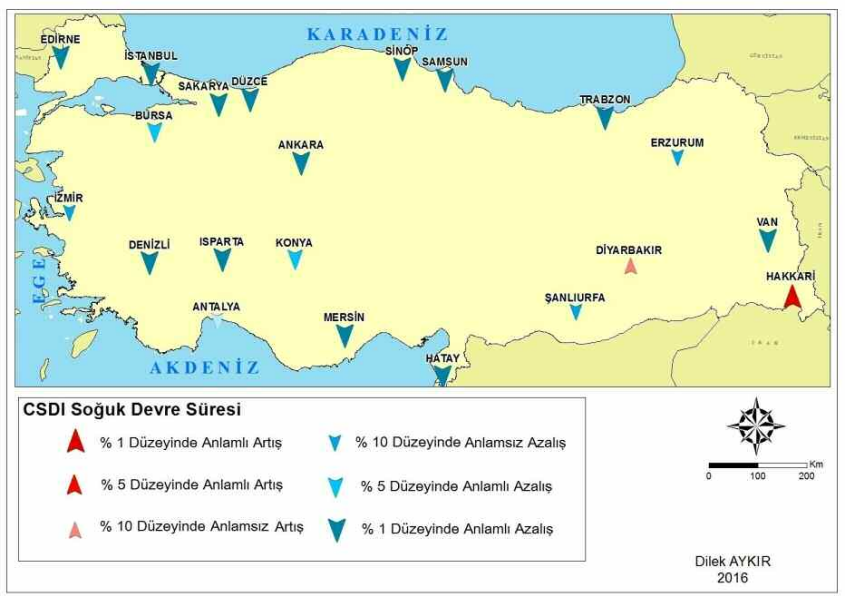

Şekil 24. Soğuk devre süresi indisi fark haritası.

Figure 24. Difference of cold period indices map.

\subsection{Günlük Sıcaklık Genişliği İndisi}

Günlük sıcaklık genişliği maksimum ve minimum sıcaklık arasındaki farkı ifade etmektedir. Şehir-kır/kasaba istasyon çiftlerinin 12 istasyon çiftinde azaldığı, 9'unda ise günlük sıcaklık genişliği indis farklarının arttı̆ı̆ görülmektedir. İstasyonların dağılışı incelendiğinde Trakya, Güney Marmara ve İç Batı Anadolu'da günlük sıcaklık farklarının azalmakta, Orta ve Doğu Karadeniz kıyıları, Ege ve Akdeniz kıyıları ve Güneydoğu Anadolu Bölgesi'nin güney kesiminde farklar artmaktadır. Günlük sıcaklık genişliğinin artması üç koşulda gerçekleşebilir. Maksimum sıcaklığın sabit kalıp, minimum sıcaklığın düşmesi ya da minimum sıcaklığın sabit kalıp maksimum sıcaklığın artması ya da minimum sıcaklığın düşerken maksimum sıcaklığın artışı ile oluşabilir. Şehir istasyonlarında minimum sıcaklıkların artı̧̧ eğilimi daha kuvvetlidir. Maksimum sıcaklık artş̧ı ise şehir kanyon etkisinin olmadığı direkt radyasyon alımının fazla olduğu kır/kasaba istasyonunda daha belirgindir. İstasyon çiftleri arasındaki 
farklarının azalması kır/kasaba istasyonlarında günlük sıcaklık genişliğinin daha hızlı azaldığını göstermektedir. Bu kır/kasaba istasyonlarında hızlı şehirleşme sonucu yüzey örtüsü değişimine bağlı olarak minimum sıcaklıkların daha belirgin olarak artışı ile ilgilidir (Şekil 25).

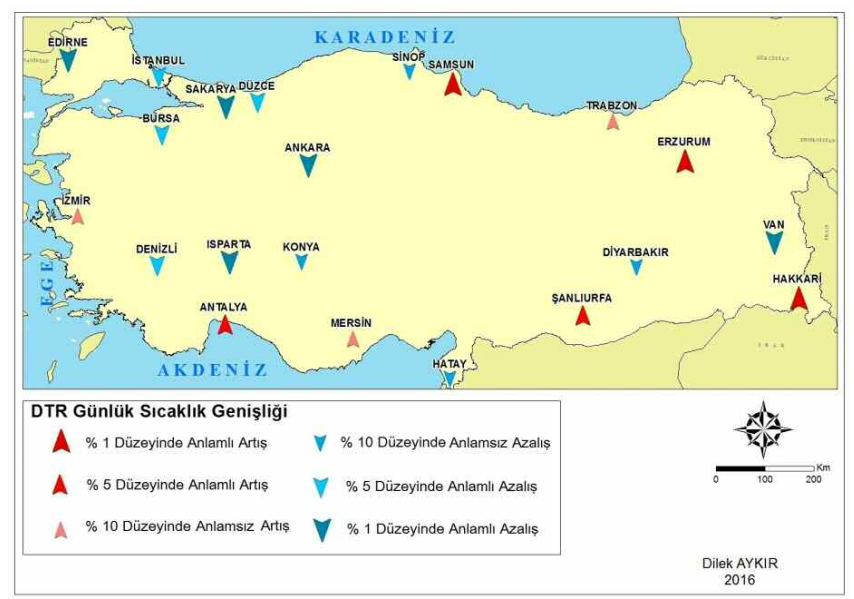

Şekil 25. Günlük sıcaklık genişliği indisii fark haritası.

Figure 25. Difference of daily temperatures indices map.

\subsection{Sıcaklık ve Nüfus İlişkisi}

Nüfus ile günlük sıcaklık genişliği arasında negatif korelasyon vardır (Tablo 3). Nüfus arttıkça günlük sıcaklık genliği azalmaktadır. Bu durum minimum sıcaklıkların maksimum sıcaklıklardan daha fazla arttı̆ını dolayısıyla sıcaklık genişliğinin azaldığını ortaya koyar. Şehirleşmeye bağlı olarak minimum sıcaklıkların artması sonucu negatif korelasyon gerçekleşir. Buna karşın şehir ısı adasının gelişimi kırlara göre şehir istasyonlarındaki gece sıcaklığını arttırır. Şehir istasyonlarında gece şehir ısı adasının etkisinden dolayı sıcaklıklar kır alanlarına göre daha az düşmektedir. Bu da farkın zaman içinde artmasını sağlamıştır. Tropik günler farkı istasyon çiftlerinde artmaktadır. Bu günlük sıcaklıkların yükselerek tropik gün sayısının arttğını gösterir. Buna karşın yaz günü sayısı azalır. Bu da sıcaklıkların yaz günleri eşik değerini geçerek tropik günlere ulaştı̆ını gösterir. Yaz ayları şehir ısı adasının iyi geliştiği aylardır. Bu da sonuç da şehirleşme etkisini gösterir.

Tablo 3. Sıcaklık ile nüfus arasındaki ilişki.

Table 3. Relationship between temperature and population.

\begin{tabular}{|c|c|c|c|c|c|c|c|c|c|c|c|}
\hline & & $\begin{array}{l}\text { Günlük. } \\
\text { Sic. } \\
\text { Gen. }\end{array}$ & $\begin{array}{l}\text { Sicak } \\
\text { Geceler }\end{array}$ & $\begin{array}{l}\text { Min. } \\
\text { Sic. } \\
\text { Max. }\end{array}$ & $\begin{array}{l}\text { Min. } \\
\text { Sic. } \\
\text { Min }\end{array}$ & $\begin{array}{l}\text { Mak. } \\
\text { Sic. } \\
\text { Min }\end{array}$ & $\begin{array}{c}\text { Max. } \\
\text { Sic. } \\
\text { Max. }\end{array}$ & $\begin{array}{c}\text { SIcak } \\
\text { devre } \\
\text { süresi. }\end{array}$ & $\begin{array}{l}\text { Tropik } \\
\text { geceler }\end{array}$ & $\begin{array}{c}\text { Yaz } \\
\text { günleri }\end{array}$ & $\begin{array}{l}\text { Soğuk } \\
\text { devre } \\
\text { süresi. }\end{array}$ \\
\hline & $\mathbf{r}$ & 0,130 & 0,169 & 0,129 & 0,251 & $-0,294$ & $-0,360$ & $-0,021$ & 0,310 & $-0,503$ & $-0,163$ \\
\hline & p & 0,575 & 0,464 & 0,577 & 0,273 & 0,196 & 0,109 & 0,927 & 0,171 & 0,020 & 0,481 \\
\hline & N & 21 & 21 & 21 & 21 & 21 & 21 & 21 & 21 & 21 & 21 \\
\hline
\end{tabular}

r. Pearson Korelasyonu p. Anlamllık N.istasyon sayısı

\section{Tartışma}

İklim değişimi dünyanın birçok bölgesinde ortalama sıcaklıklarda meydana gelen önemli değişiklikler şeklinde kendini göstermektedir. Örneğin; 1996-2005 döneminde küresel ortalama, sıcaklıklarda gözlenen artş $0,74{ }^{\circ} \mathrm{C}^{\prime} \operatorname{dir}$ (Türkeş, 2007).Yaklaşık 10 yıl öncesine göre, ortalama ve maksimum sıcaklıklarda soğuma eğilimlerinin zayıfladığını ve daha az anlamlı hale geldiğini ve bu değerlerin özellikle ilkbahar ve yaz mevsimlerinde meydana geldiği gözlenmiştir (Türkeş vd., 2002). Küresel ortalama yüzey sıcaklığında gözlenen ısınma eğilimi, dünya üze- rinde her yerde eşit dağılım göstermemekle beraber $40^{\circ}-70^{\circ} \mathrm{K}$ enlemleri arasındaki karalarda uzun süreli ısınma eğilimi daha fazla gerçekleşmektedir (Türkeş, 1995). Kıyı bölgelerde farklar daha az iken, karasallık etkisinin görüldüğü iç kesimlerde farklar daha belirgindir (Şensoy vd., 2008). Dünyadaki tüm bu genel ısınma trendinin yanında bu ısınma her yerde aynı oranda olmamaktadır.

Minimum sıcaklıkların minimumu dünya genelinde artma eğilimi göstermektedir. Yapılan birçok çalışmada "kentsel boyutun şehir Isı adası üzerindeki etkisi" ortaya konmuştur (Mohsin ve Gough, 2012). Hızlı şehirleşme, minimum sıcaklıklar üzerindeki en büyük etkiyi yapmaktadır. Dünyadaki genel ısınma ve buna bağlı olarak şehirleşme sıcak geceler sayılarının artışına neden olmaktadır. IPCC raporları tüm dünyada sıcak geceler sayısının arttı̆̆ını ortaya koymaktadır.

Hızla büyüyen şehirlerin çevrelerine oranla yüzey değişimleri nedeniyle farklı albedo özelliklerine sahip olarak ısı alış veriş koşulları değişmektedir. Bunun yanında bu alanlardan atmosfere verilen kirleticiler ve zaman zaman oluşan (şehrin kurulduğu alanın topoğrafya özelliklerine de bağı olarak) inversiyonlar neticesinde iklim özelliklerinde değişimler gözlenmektedir (Gönençgil, 2011). Çiçek'in Ankara şehrinde şehirleşmenin yağış üzerine etkisi ile ilgili yaptı̆̆ çalışmada ayrıca kentsel alanlardaki aşırı nüfus artışının, betonarme yüksek binaların oluşturduğu kanyon etkisi, asfalt alanlarındaki artış, yeşil alanların azalması, sanayi tesislerinin artması ve şehir merkezlerinin içinde kalması gibi etkenlerden dolayı sıcaklıklardaki artş̧ların son 50 yıldır insan etkisine bağlı olarak daha fazla arttı̆̆, bu artş̧ın kentsel alanlarda kırsal alanlara göre daha belirgin olduğu kanıtlanmıştır (Çiçek, 2005). Bu durum tüm dünya için özellikle içinde bulunduğumuz Akdeniz havzası için önümüzdeki yıllarda ciddi bir sorun oluşturacaktır. Şehir planları yapılırken topografya göz önüne alınmalı ve hava sirkülasyonunu engellemeyecek şekilde planlanmalıdır. Rüzgârlar şehirsel alanlarda normalden daha farklı bir mekanizma gösterirler. Rüzgâr hızı, şehirlerde açık su yüzeylerinde olduğundan daha azdır (Chandler, 1962). Diğer yandan caddelerin konumu ve gökdelenlerin varlığı rüzgârların lokal sirkülasyonuna neden olur. Şehir iklimi ile ilgili yapılan çalışmalarda (Charley ve Barry, 1982, (Christopherson, 2002), (Landsberg, 1981), (Oke, 1987), (Bornstein, 1968) Şehir Isı Adası etkisini iyileştirmek için belirli bir rüzgâr hızına ihtiyaç olduğu sonucuna varılmıştır. Ancak bu hızın üzerinde olan rüzgârlar, şehir üzerindeki toz ve ısı kubbesini dağıtmayı başarabilirler. Şehir planlamasında büyüklü küçüklü binaların bulunduğu yapılar yerine az katlı ve aynı boyutlarda yapıların inşa edilmesi gereklidir. ABD ve birçok Avrupa ülkesinde yaygın hale gelen yeşil çat uygulaması ve sarılıcı bitkilerin bina cephelerinde daha çok kullanılması ISı adası etkisini azaltıcı tedbirlerdir. Peyzajda bitkilerin merkezden çevreye hâkim rüzgâr yönünde tesisi hava sirkülasyonu açısından uygun olacaktır. Endüstriyel duman salınımları ve fosil yakıt kullanımı en aza indirilerek doğalgaz kullanımı teşvik edilmelidir. Sanayi tesisleri şehir içinde ve depresyon alanlarında inşa edilmemelidir. Depresyon alanlarında inşa edilen sanayi tesislerinin kirli havası, havanın bu basık alanda toplanmasına neden olacak ve ventilasyona engel olacaktır (Kum ve Kılıç, 2013).Türkiye'de şehirlerin çoğunda tek istasyonun bulunması iklim elemanlarının alansal dağılışının net bir şekilde incelenmesini engellemektedir. Şehirleşmenin etkisini sağlıklı bir şekilde ortaya koymak ve kontrol etmek bakımından şehir merkez ilçeleri 
ile şehirsel gelişim potansiyeli olan kesimlerde klima ölçüm istasyonlarının kurulması gerekmektedir.

\section{Sonuç}

Sonuçlar göstermektedir ki; küresel iklim değişimi sonucunda artan sıcaklıklar yaz günleri sayısında da artş̧a neden olmaktadır. Yaz günleri indis farkı istasyonların çoğunda anlamlı bir şekilde azalmaktadır. Nüfusu fazla olan şehirlerle kır/kasaba istasyonları arasındaki farklarda azalma daha belirgindir. Tropik geceler indis farkı tüm Türkiye'de genel olarak anlamlı artı̧ eğilimi göstermektedir. Bu anlamlı artı̧̧ şehirleşme etkisinin sıcaklık ve sayılı günler üzerindeki etkisini ortaya koymaktadır. 21 istasyon çiftinin 13'ünde tropik gün sayıları indis farklarında artış görülürken 8'inde azalma görülmektedir. Trendlerin çoğu \%5 seviyesinde istatistiksel olarak anlamlıdır. Dünyada özellikle şehirleşme sonucunda minimum sıcaklıklar artış göstermektedir. Şehirleşmenin belirgin olduğu alanlarda minimum sıcaklıklar daha hızlı artı̧̧ göstermektedir. Seçilen istasyonların çoğunda şehirleşme sonucunda minimum sıcaklıkların maksimumunda daha hızlı artış olduğunu göstermektedir. Günlük maksimum sıcaklıkların minimumu dünyadaki küresel sıcaklığın artışının ısınma açısından önemli bir göstergesidir. İstasyonların 18 'inde bu farklardaki artş ve azalışlar belirgin değildir. Çünkü şehirleşme minimum sıcaklıkları maksimumlardan daha çok etkilemektedir.

Seçilen istasyonlarda Türkiye'nin bat kıyısında ve güneyindeki istasyon çiftlerinde sıcak geceler indis farklarında anlamlı artı̧lar görülmektedir. Bazı istasyonlarda sıcak geceler indis farklarında azalma görülmesi kır/kasaba istasyonlarında sıcak geceler sayılarının daha hızlı arttğını ortaya koymaktadır. Fakat artış gösteren istasyonlarda anlamlılık düzeylerinin 0,01 olması tüm Türkiye'de sıcak gece sayılarında şehirleşmeye bağıı olarak artı̧̧ eğiliminin daha belirgin olduğunu göstermektedir. İncelenen istasyon çiftlerinin çoğunda sıcak devre süresi indis farklarında azalış görülmektedir. Bu azalışın tüm istasyon çiftlerinde (şehirkır/kasaba) anlamlı olması genel bir ısınma trendinde olduğunun bir ispatıdır. Bunun yanı sıra şehir istasyonlarındaki sıcak devre süresindeki artış kır/kasaba istasyonlarına göre daha fazladır. Bu durum şehirlerde bu sürenin daha fazla arttı̆ını göstermektedir. Genel anlamda seçilen şehir ve kır/kasaba istasyonlarının soğuk devre süreleri indis arasındaki fark anlamlı bir şekilde azalmaktadır. Bu durum şehirlerdeki ısınma etkisi ile minimum sıcaklıkların normalin $\% 10$ altında 6 ardışık günün şehirlerde daha az görüldüğünü, kır/kasaba istasyonlarında bu etkinin devam etmesi aradaki farkın azalmasına neden olmaktadır. Soğuk devre süresi indis farkının istasyon çiftlerinde azalması şehirleşme etkisiyle soğuk hava dalgalarının şehirlerde daha az etkili olduğunu ortaya koymaktadır. Günlük sıcaklık genişliği indis farkı 12 istasyon çiftinde azalmakta, 9 istasyon çiftinde ise farkın arttğı görülmektedir. Trakya, Güney Marmara, İç ve Batı Anadolu'da farklar azalırken, Orta ve Doğu Karadeniz kıyıları, Ege ve Akdeniz kıyıları ve Güneydoğu Anadolu Bölgesi'nin güney kesiminde farklar artmaktadır. Şehirlerde minimum sıcaklıklar daha belirgin iken, şehir kanyon etkisinin olmadığı kır/kasaba istasyonlarında maksimum sıcaklık artışı daha belirgindir. İstasyon çiftleri arasındaki farkların azalması kır/kasaba istasyonlarında günlük sıcaklık genişliğinin daha hızlı azaldığını göstermektedir.

\section{Kaynakça}

Acar, Z. (2013). "Türkiye'de Yaz Mevsimindeki Sıcak Günler Ve Sıcak Günlerin Eğilimleri ", Türk Coğrafya Dergisi, 1-10.

Aguilar, E. M., Brunet, M., Peterson, T., Wieringa, J. (2003). "Guidelines on Climate Metadata and Homogenization". World Meteorological Organization 53, 55-65.

Alexander, L., Zang, X., Peterson, T., Rupa, Taylor, M., New, M., Klein, T. A., Haylock, M., Aguilar, E. M., Brunet, M., Kumar, R., Taylor, M., New, M., Zhai, P., Rusticucci, M., Vazguez, A. J. L. (2006)."Global Observed Changes in Daily Climate Extremes of Temperature and Precipitation". Journal of Geophysical Research 111,1-22.

Alghamdi, A, Moore, T.,W. (2014). "Analysis and Comparison of Trends in Extreme Temperature Indices in Riyadh City, Kingdom of Saudi Arabia, 1985-2010". Journal of Climatology Volume. Article ID 560985,. http://dx.doi.org/10.1155/2014/560985.,1-10.

Auer, A. (1975). "The production of cloud Physics Aitken Nuclei by the St. Louis" Metropolitan Area. Rech-atm. 9-1, 11-22.

Bornstein, R. (1968). "Observations of the Urban Heat Island Effect in New York City". J. Appl. Meteor. 7, 575-582.

Chandler, T., (1962). "London's Urban Climate". Geography Journal. 128,279-298.

Charley, R., Barry, R., (1982). "Atmosphere Weather and Climate".USA,82-120.

Christopherson, R., (2002). "Man-Made Climate". Geosystems:An Introduction to Physical Geography, USA, 262-296.

Çiçek, I.., (2005). "Ankara'da Şehir ve Kırsal Sıcaklık Farklarındaki Değişiklikler (1970-2002)". Fırat Üniv. Sos. Bil. Dergisi 15.2,1-16.

Çiçek, I.., (2004)."Ankara'da Şehirleşmenin Yağış Üzerine Etkisi". Fırat Ünv. Sosyal Bilimler Dergisi 14.1, 1-17.

Çiçek, İ., Türkoğlu, N., (2005). "Urban Effects on Precipitation in Ankara". Atmosfera 18.3,172-186.

Çiçek, İ., Doğan, U., (2005). "Ankara'da Şehir Isı Adasının Incelenmesi". Coğrafi Bilimler Dergisi 3.1,57-72.

Çiçek, i.., Türkoğlu, N., (2009). "The Effects Of Urbanization On Water Vapour Pressure In A Semi-Arid Climate". Theorotical and Applied Climatology 95,125-134.

Demir, i., Kılıç, G., Coşkun, M., Sümer, U., (2008). "Türkiye'de Maksimum, Minimum ve Ortalama Hava Sıcaklıkları Ile Yağış Dizilerinde Gözlenen Değişiklikler ve Eğilimler". TMMOB İklim Değişimi Sempozyumu Bildiriler Kitabı, 69-84.

Demircan, M, Arabaci, H., Bölük, E., Akçakaya, A., And Ekici, M., ỉklim Normalleri: Üç Sıcaklık Normalinin Iliş̧kileri Ve Uzamsal Dağılımları, III. Türkiye İklim Değişikliği Konferansı - TiKDEK 2013, 3 - 5 Haziran, 2013, ITÜ - Süleyman Demirel Kültür Merkezi, İstanbul - Türkiye. http://www.mgm.gov.tr/FILES/iklim/iklim-normalleri.pdf

Dixon, P.G., Mote, T., (2003). "Patterns and Causes of Atlanta's Urban Heat Island İnitiated Precipitation". Journal of Applied Meteorology, 1273-1284.

Erlat, E., Yavaşlı, D.D., (2009). "Ege Bölgesi'nde Tropikal gün ve Yaz Günü Sayılarındaki Değişim ve Eğilimler". Ege Coğrafya Dergisi 18/(1-2), 1-15.

Ezber, Y., Şen, Ö. L., Karaca M., (2007). "İnvestigation of Urbanization Effects on Climate in İstanbul: Using Statistical and Dynamical Techniques". Eurasia Institute of Earth Sciences, 667-679.

Gallo, K., (1993)."Use of NOAA, AVHRR Data for Assesment of The Urban Heat Island Affect USA". Journal of Applied Meteorology 32, 899-908.

Gönençgil, B., (2011). "Şehirleşmenin Sıcaklık Trendleri Üzerine Etkileri ve Şehirsel Isı Adası Kavramı". Türk Coğrafya Kurumu Yayını 6, 127136.

Hough, M., (1984). "City Form and Natural Process". Cromm Helm, 286-320.

Hamidi, N., Toprak, F., (2007). "GAP Bölgesinde Yıllık Toplam Yağışların Değişimi ve Homojenik Analizi". Türkiye İklim Değişikliği Kongresi, 86-92.

IPCC , (2001). "The Third Assessment Report". The Intergovernmental 
Panel on Climate Change, 22-47.

IPCC, (2007). "The Fourth Assessment Report". The Intergovernmental Panel on Climate Change, 28-73.

IPCC, (2013). "The Fifth Assessment Report". The Intergovernmental Panel on Climate Change, 159-203.

Kadıŏlu, M., (1993). "Türkiye'de İklim Değişikliği ve Olası Etkileri". Çevre Koruma Dergisi 47, 34-37.

Kalaycı, S., Kahya, E., (1998). "Susurluk Havzası Nehirlerinin Su Kalitesi Trendlerinin Belirlenmesi". Turkish Journal of Engineering and Environmental Science 22, 503-514.

Klein, T., A., Können, G., (2003). "Trends in Indices of Daily Temperature and Precipitation Extremes in Europe 1946-1999". Journal of Climate 16, 3665-3680.

Kum, G., Kılıç, Ş., (2013). "Şehirleşmenin Sıcaklık ve Yağış Parametreleri Üzerine Etkisi: Antep Örneği". Sosyal Bilimler Dergisi 3.6, 23-39.

Landsberg, H., (1981). "The Urban Climate". Academic Press, 221-260.

Li, Q., Huang, J., Jiang, Z., Zhou, L., Chu, P., Hu, K., (2014). "Detection of Urbanization Signals in Extreme Winter Minimum Temperature Changes over Northern China". Climatic Change 122, 595-608.

Libiseller, C., Grimwall, A., (2002). "Performance of Partial Mann Kendall Tests for Trend Detection in The Presence of Covariates". Environmetrics 13.1, 71-84.

Marsh, W., (1991). "Landscape Planning, Environmental Applications". 2nd Edition, 202-253.

Mohsin, T., Gough, W.A., (2012). "Characterization and Estimation of Urban Heat Island atToronto: impact of the choice of rural sites". Theoretical and Applied Climatology 108, 105-117.

Oke, T., (1987). "Boundary Layer Climates". 2nd Edition, 435.

Partal, T., Kahya, E., Seker, D., Kabdaslı, S., (2003). "Pecipitation Trends in the Aegean Region". International Association of Hydraulic Engineering and Research Congress, Greece, 15.

Sneyers, R., (1990)."On the Statistical Analysis of Series of Observations". WMO Technical Note 143, 192.

Şensoy, S., Demircan, M., Alan, Ü., (2008). "Trends in Turkey Climate Extrme Indices from 1971 to 2004". IV. Atmosfer Bilimleri Sempozyumu Bildiri Kitabı, 453-460.

Sensoy, S., Demircan, M., Alan, I.., 2008, 1971 - 2004 Yılları Arası Türkiye İklim İndisleri Trendleri, D.M.i. web sitesi, http://www.dmi.gov.tr/FILES/iklim/turkiye_iklim_indisleri.pdf

Sensoy, S., Türkoğlu, N., Akçakaya, A., Ekici, M., Demircan, Mesut., Ulupınar, Y., Atay, H., Tüvan, A., Demirbaş, H., Trends In Turkey Clımate Indices From 1960 To 2010, 6th Atmospheric Science Symposium - ATMOS 20133 - 5 Haziran 2013, Istanbul, https://www.mgm.gov.tr/FILES/iklim/trendsin-turkey.pdf

Sensoy, S., Türkoğlu, N., Çiçek, i., Demircan, M., Arabacı, H. And Boluk, E., Urbanization Effect On Trends Of Extreme Temperature Indices In Ankara, VII. Uluslararası Katılımlı Atmosfer Bilimleri Sempozyumu, 28-30 Nisan 2015, İstanbul Teknik Üniversitesi İstanbul Aydın Üniversitesi, İstanbul, Türkiye, h tt $p$ : / / w w w . a t mosfer. it u. ed u. tr/w pcontent/uploads/2015/05/Cilt2.rar

Tatlı, H., Dalfes, N., Menteş, S., (2004). "A Statistical Downscaling Method For Monthly Total Precipitation Over Turkey". International Journal Of Climatology 24, 161-180.

Türkeş, M., (1995). "Türkiye'de Yıllık Ortalama Hava Sıcaklıklarındaki Değişimlerin ve Eğilimlerin İklim Değişikliği Açısından Analizi". Çevre ve Mühendislik Dergisi 9, 9-15.

Türkeş, M., (1996). "Spatial and Temporal Analysis of Annual Rainfall Variations in Turkey". International Journal of Climatology 16, 1057-1076.

Türkeş, M., (2002). "Küresel Isınma Rekor Kırıyor". Tübitak Bilim ve Teknik Dergisi 370, 20-21.

Türkeş, M., Sümer, U., Demir, İ., (2002). "Türkiye'nin Günlük Ortalama Maksimum ve Minimum Sıcaklıkları ile Sıcaklık Genişliğindeki Eğilimler ve Değişiklikler". Prof. Dr. Sırrı Erinç Adına Klimatoloji Çalıştayı Bildiriler Kitabı, 89-106.

Türkeş, M., (2007). "İklim Değişikliği Nedir? Temel Kavramlar, Nedenleri, Gözlenen ve Öngörülen Değişiklikler". I. Türkiye İklim Değişik- liği Kongresi Bildiriler Kitabı, 38-53.

Türkeş, M., (2010). "Klimatoloji ve Meteoroloji". Kriter Yayınevi, 206.

Türkoğlu, N., Çalışkan, O., Çiçek, I., Yılmaz, E., (2012). "Şehirleşmenin Biyoklimatik Koşullara Etkisinin Ankara Ölçeğinde İncelenmesi". Uluslararası İnsan Bilimler Dergisi 9.1, 933-954.

Ustaoğlu, B., (2012). "Trend Analysıs of Annual Mean Temperature Data Using Mann-Kendall Rank Correlation Test in Çatalca-Kocaeli Peninsula, Northwest of Turkey for the period of 1970-2011". IBAC ( International Balkan Annual Conference) vol.2, 276-287.

Xiaolan, W., (2003). "Detection of Undocumented Changepoints: A Revision of The Two-Phase Regression Model". Journal of Climate 16, 3383-3385.

Xoplaki, E., Gonzalez, R., Jesus, F., Luterbacher, J., Wanner, H., (2003). "Mediterranean Summer Air Temperature Variability and Its Conneciton to The Large-scale Atmospheric Circulation and SSI". Climate Dynamics 20, 723-739. 
